\title{
Promoting freedom in education. Study of a case.
}

\author{
Salvador Peiró i Gregòri, PhD \\ Theory and History of Education. Interdisciplinary Research on Indiscipline, \\ Violence and Values in Education (Peaceful-Coexistence and School Incivility).
}

\begin{abstract}
Contextualized the value "freedom" in relation to current problems, the liberty's and various ways of conceiving freedom is defined, as well as the demands that their metaphysics and anthropology demand. Then it is interpreted in relation to human rights and other values, human and social virtues, etc., pointing out the way of presenting values' freedom in schools' conflict. Then the main models and procedures to promote them are considered, with the possible curricular derivations. The aims are related with the followed heuristic issues: a) How to teach humanitarian principles? b) How to promote Human Rights? c) What issues and values are promoted through the curriculum? d) Related to freedom, what issues \& values are promoted? e) Are there contradictions in the teachings? $\mathrm{f}$ ) Is it possible to implement this model? g) Is it possible to carry out such a model-value? The method of research is analytical, transversal case study, without sample type and size, taking advantage of only the opportunity to interview. But, before a phenomenological and hermeneutical procedure was made, configuring a network to interpret axiological skills results' for the questionnaire's items. The population had surveyed wear teachers and students. The distribution by years/population is as follows: 2008: 1130, 2009: 995, 2010: 1468, 2011: 959. With a questionnaire, a provincial reality is analytical-empirically studied. Defining the model as proceduralist, proposals to supplement it are offered. Main conclusions: The issues and values related with freedom are promoted through the curriculum are consistent with the statements mentioned in the theoretical framework. The results of teaching and learning do not remain in mere rational exercise. The teaching of peace are understood in the curriculum does not follow that it develops more personalizing than intellectual. The found model is largely procedural. The education for full freedom is not complete, because it is not clear that there are content with human values. On Human Rights' education, there is a certain ambiguity between the transversal and notional of values and themes. Teaching the curriculum development is insufficient, so it shall be possible to implement an integrated model.
\end{abstract}

Keywords: Freedom's values. Human rights. Models of values education. Theory of "freedom".

\section{INTRODUCTION}

Elzo (2006) exposes the contradiction between the finalist values (freedom, equality, justice, solidarity ...), which are very appreciated by young people, and a weakness of the instrumental values (commitment, effort, dedication...), who train to practice the first ones. This litigation can be a factor of contradictions and conflicts (Fernández-Llébrez, 2009). Besides near 70\% millennials don't think it's essential to live in a democracy, and a growing number of young Americans think democracy is a bad way to run the country, so the number of citizens who desire army rule has gone up in most democracies around the world (Foa \& Munk, 2015). The paradox is that in Spain is the old people who resist the arrival of tyrants, while in Venezuela are the young (Rubiales, 2017). Postman claims students are asked to several "false gods": economic, consumerism... (Levinson, 1995), which leads to critical situations.

Given this, suspension and expulsion from school are used to punish students, alert parents, and protect other students and school staff. In front of crisis into schools, highlights aspects of 
expulsion and suspension that jeopardize children's health and safety. This is because these may exacerbate academic deterioration, and when students are provided with no immediate educational alternative, student alienation, delinquency, crime, and substance abuse may ensue (CSH, 2003).

Moreover, we have situations related to immigration that are creating problems arising from multiculturalism, who promptly reach even racism; also, free partisan models on educational policies has to be added, etc. Among the mentioned aspects, there is another type of conflicts in certain autonomous communities, parents and teachers face each other for linguistic reasons, for gender ideology, for the teaching of religion, etc., similarly with language, mathematics and the way they are taught (Powell, 2010).

To interpret this wrongly carries wrongdoing, why has been observed that our society does not work well (Soëtard, 2011; Peiró, 2008). One of its factors is because the social and economic development is linked to freedom (Cabello, 2003; O'Hearn, 2009). But, as there is no consistency between freedom and intellectual training/implementation (Moshman, 2003), there are conflicts. We know citizenship is connected to values, as opposed to the authoritarian model (Dovemark, 2004: 657ss).

\section{THEORETICAL FRAMEWORK}

Liberal democracy is the institutionalization of Human Rights, as a most practical solution to the freedom of each human being compatible with the freedom of all. Related this with the introductory context, conflict has been inescapable public schooling reality (Unicef, 2011). The democratic way of life aims at allowing individuals some measure of control over their lives and allows for a pursuit of unique potential rather than being passively impacted by external, uncontrollable forces in a futile attempt at isolation (Jackson, 2014, p.16, in Beesley, 2016). Necessary attendance to a formal institution is subject to legal penalties and social conflict, inflicting upon people's liberty and property.

Furthermore, it is neither sufficient to describe us as a field or to assert we are free. Some larger ethical and philosophical view (Millán-Puelles, 2009) of humanity must serve as a framework to integrate basic assumptions and help select eventual solutions to our problems. Because the person is free for to be cause of their own actions (Fabro, 1983: 22-25). However, it is not absolute independence, that emancipation it slows down the social coordination (Meyer, 2007). So, in the current democracy, education must solve the contradiction freedom/authority, which solution guarantees certain order (Cociña, 1991), wich leads to the development of the personality. The key to this goal consist on to cultivate the critical awareness (Duvemaril, 2010), because the intrinsic root of freedom is free reasoning-willing (García-López, 1991).

Consistently, anyone born personally free (Reyero, 2003) because it not born with civic values. Moreover, the free human no man confers to himself. This means the free will is not given to man in a purely natural way, however, because of what was said before, we have the need to educate it (Millán-Puelles, 1988, 65-66). And this kind of education is possible and necessary if exploited the innate potential of self-control that the person essentially has. This is an aspect of innate dignity of man as a person (Millán-Puelles, 2009, 59).

Regarding personal citizenship, a free person is not only who is not in coertion; the idea, inherited from the conflicts of the seventeenth century, that a free society - one governed by principle and by law - is a necessary condition of personal freedom (Sedley, 1999, Ch.1). So without a citizen may choose, but he is limited by the law (Dürr, 1971:18), so there should be 
rights and duties (Lalande, 1967:575ss). And these are prepared from family and school education.

In this regard, it has been shown that very different individuals, working in different levels of education and with different intellectual interests, can give rise to a learning environment in which freedom prevails with responsibility, generating more and better cultural results (Rogers, 1996, chp.1). By consequence, there will be a new indicator of educational quality: liberty-creativity (Mazón, 1974).

To understand the nature of freedom remember the thesis of Millán-Puelles: It is accident, not substance; each one has it, but to be it is not enough, because it is not absolute, but relative. Regarding the 'subject' of freedom, it depends of a principle or cause. Regarding its 'object', it is 'freedom of indifference'. Freedom is of two types: an inferior, innate; and another superior, acquired. The innate is triple: the double 'transcendental' of the understanding and of the will and the free will (libero albedrio) of the will. Seeing it as acquired, this is double: civil and moral. It derives from necessities and is subordinated to those. So, freedom is limited. The maximum form of freedom is the 'election' of God (Sellés, 2014, 189-224).

Besides, social lives are closely related to communication as education is defined as the acquiring of a body of knowledge through systematic instruction that is to an individual, enlightening. Civic life and therefore specialization can expand human educational experiences as a necessity, by virtue either of logic or of natural law and to advance ones 'life' or human existence and flourishing (Beesley, 2016).

The before introductory brushstrokes do not express that educating for freedom is not the same as educating in freedom. The reason is that the freedom of, in and for it, there are no citizens capable of deciding for themselves. Of the last we can see example from Norway in matter of Religion.The freedom of religion in Constitutional's clause is a case in point and illustrates the complexity and challenges stating faces when these seek to harmonize national law with international human rights (Vik \& Endresen, 2017), which is related to conflicts, that has changed in many ways since the introduction of the four freedoms (of speech, of worship, from want \& from fear).

Nevertheless, education provides a unique contribution to mitigating and transforming the causes of violences, as recognized by the 2015 Sustainable Development Goals. Considering the multicultural situation as risk, the activities in the classrooms and out-of-school over time, schools and non-formal education activities can promote the respect of human rights and values, thus allowing more inclusive societies and strengthening the social cohesion (Connolly \& Ospina, 2016).

The benefits of educational freedom are: social harmony; improved equity; greater diversity, innovation, and quality (Cato Institute, 2017). Consequently, educational choice is individual human action, therefore enforced state education ignoring individual diversity by an uniformist national curriculum set by the bureaucratic process prevents, or ignores the practice of freedom. On avoiding this, teachers must rethinking of the means, methods, and institutions most suitable for the values education of the child (Ryan in Rothbard, 1999, p.5).

Human perfection (happiness) is activity in accordance with the moral and intellectual virtues." (Wiles in Trapani, 2004, 92). Education would then require more specialisation as there would be a need for more general social and moral rules (e.g. rules for the whole 
community), but there would also need to be more specific social and moral standards which apply to specific interactions (Brook et al., 2014, p.4) tells Beesley (2016).

Musso (2003), from considering inhuman acts, motivates us to distinguish morally those of man (natural) as they are derived from physiological functions and unconsciousness, from the strictly human, which come from the intellectual valuation, by which, the conscience emits attitudes (like intentions, purposes) to act with will, that is, freely. In this sense, an act of resentment or anger towards someone, even if it is not perceived by the surrounding people, is conditioning the sociality of the person who suffers it. This is so because the community (polis) is the place where freedom can be manifested and, if carried out in an unreflective way and linked to the material, the subject becomes dehumanized (Arendt, 2002).

Depersonalization is that experience characterized by a feeling of detachment from one's own body or mental processes, with symptoms of identity confusion. It is a feeling of uncertainty, perplexity, or conflict over who students are. The main dissociative symptoms are the depersonalization and a derealisation (Torto, 2013). That is because each individual develops a personal framework of meaning which may vary from an inconsistent mishmash to a thoughtfully integrated network of beliefs and values. Hence there is a need to help students understand this connection and to inspect some of the more fully articulated life stances influential in their culture (Hill, 2004, 7-9). Corollary, it will be understand that this must begin by developing awareness and reflection (discernment) among schoolchildren in relation to civic and moral behavior.

Nowadays, at schools nobody talks about "good" and "evil", because people usually talk about values. Political parties discuss on values; Constitutions are considered as "value systems". Supposedly we live in a time of declining values, or perhaps values that are changing ... However, talking about values is both trivial and dangerous. It is trivial because each community, even if it promotes plurality, must share certain things that its members consider valuable ... talking about the State as a "community of values" is dangerous, since it tends to undermine this secular principle in favor of a dictatorship of political convictions (Spaemann, 2001).

Therefore the end of education is not only being autonomous (understanding this as individual independence of others), but to be educated to self-control (Foray, 2011:343ss). Therefore, education is not only to normalize, because there is some need to press to promote attitudes as responsibility, respect, recognize the fault, etc. (Dürr, 1971,114). Therefore, education in \& for freedom requires to build other values with it (Peiró, 1996, 1999...) in order to develop the project of life (Touriñán, 2006).

Otherwise, various ideologies for decades have considered certain partial dimensions of the human being as absolute values and, in doing so, have generated clamorous injustices to establish in the world a kind of tyranny of normality, that world is inevitably dehumanized (Agulló, 2013). Human willing (libero albedrio) does not have the highest value among all that man can possess, because beyond the value of this form of freedom is the value of freedom that is achieved with moral virtues (Millán-Puelles, 2009, 173). Therefore, it is necessary to recover the sense of education, even if it is with minimum values that promote the global dignity of each student and teacher.

One way to reintegrate common sense into educational processes could be to consider the dependence that freedom has on other human virtues. For this we will reflect on everyday life, making Figure 1. This example that follows should be taken as such. Each subject would make 
his phenomenological way. What we want to highlight below is that freedom itself has no validity without being "filled" by other human values, like the other social virtues, because they would be hollow, they would be mere talk.

Figure 1. The social values need the human values to be effective (Peiró, 2002).

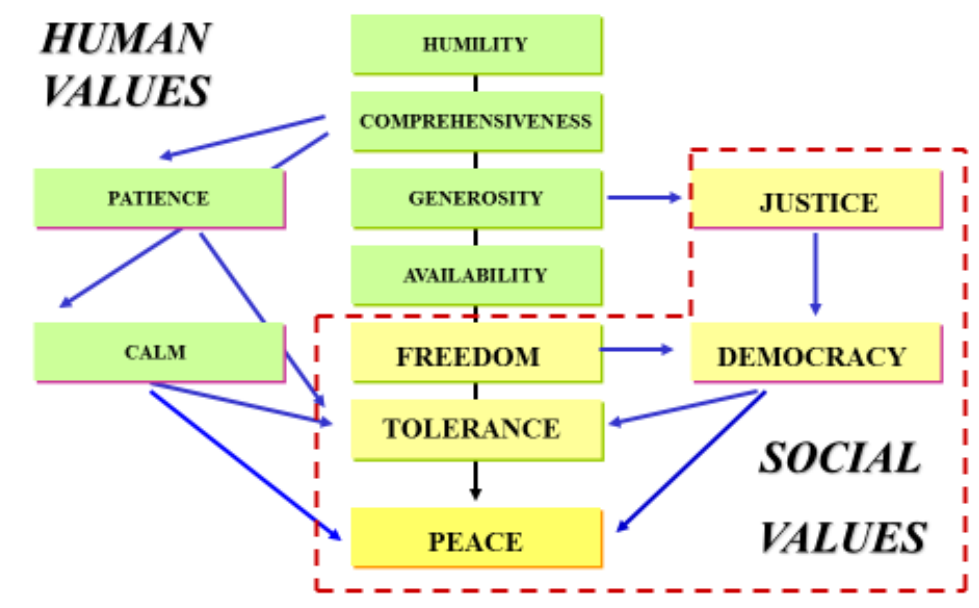

Starting from below we have: a classroom must perform the exercises in peace, for which tolerance is required; nevertheless, a student will not tolerate if he does not perform in freedom. This last virtue will facilitate democracy. However, free will is not possible if a subject is not willing to show availability, an aspect that depends on their generosity. But, if someone don't understand the situation and its meaning, then they can't know how to be generous, since this would mean not knowing to whom this value applies. However, humility is required for such a task (which is not an inferiority complex). The reinforcement of freedom emerge from the last two: patience and meekness; as well as justice as pro-democracy freedom.

Absolute freedom does not exist, since a person is a slave to his limitations and the imposedby the world around him. Thus, we have two types of limits: natural and social. The combination of both positive and negative potentials give normal or conflicting behaviors, with higher or lower levels of values, as the figure 2 offers. Those in the educational field, as they are the object of general systematization, are the latter. Such are those that we impose ourselves to live with the other members of the classrooms. For which it has to know the values that have to be practiced and, when living them, they must possess some virtues or habits, which are the qualifiers of the educational action. 
Figure 2. Differences in values between students (Peiró, 2008).

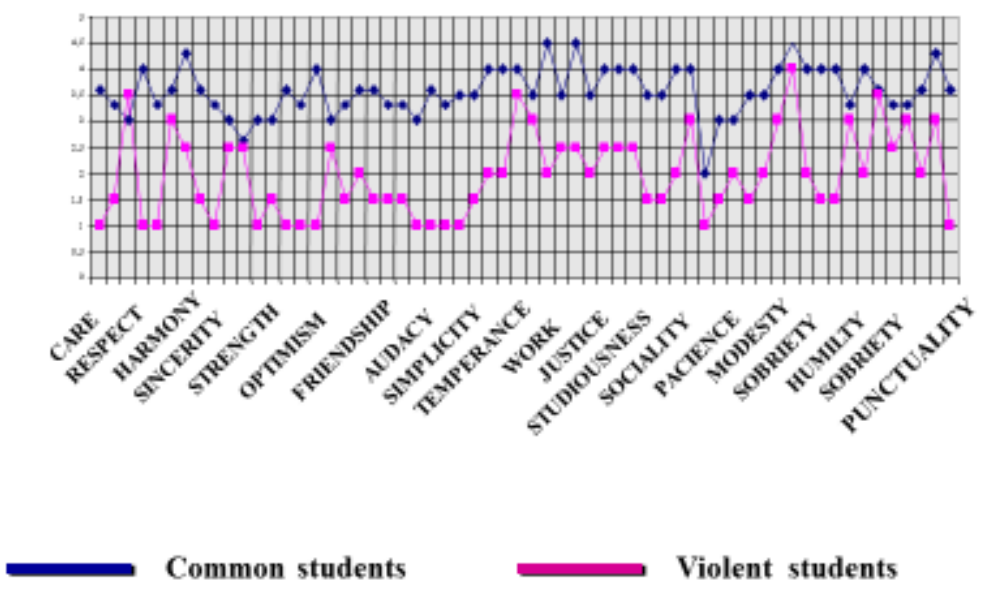

Source: Peiró, \$. (2005). Indisciplina y violencia escolar. Instituto Alicantino de Cultura, del CSIC.

The example of Figure 2 consists on two series of points are presented, joined by segments. Each point indicates the position of the attitudes or habits practiced by the students. The series located at the top corresponds to the common students; the one plotted below the previous one refers to the violent ones. This denotes several theses: a) There are no students without values (all have dignity). b) Those who find in the row above show a higher level in the value constitution of their subjectivity; those of the lower part, manifest more deficiencies in virtues. From which we infer that the values provide criteria to discern coexistence behaviors, as well as inject strength to carry out the purposes. As a result, education must include them in their designs.

There are supporters of considering values and moving coexistence through rules and lessons. This means a depersonaliation and generates conflicts (Peiró, 2001). Others say education only has to raise values and that the rules should be generated spontaneously among students, as well as let them look for the science subjects' information that each one needs. This causes uncertainty, insecurity and conflicts. Between the romanticism or primacy of the valoral sentiment, and the rigorism or primacy of the regulation, a middle term must be programmed, the law as an expression of the general good willed by man, but guided by values.

However, pedagogical models can't teach and make that all behave with identical values of schools, even if they are minimal (Hjort, 2006; Spaeman, 2011). This proposal takes us to integrate human rights and other ethical principles in the construction of the qualitative model of education (Peiró, 1982a; Wahlström, 2009). Notwithstanding doing it not multidisciplinarily, but integrating them into the lessons (Peiró, 1981, 1982 ${ }^{\text {; }}$ 2008; Nyroos et alii, 2004; Philippou, 2005). All this is made from an civical humanism (Irizar et alii, 2010), that goes on beyond the mere technical instruction (Delgado, 2010), because there is no neutrality in the teaching of unethical contents (Barrio,2003:139-145), since in the curriculum development are involved in and are interpreted rules with values to introduce rights and duties (Gonçalves, 2004, 147ss). 
Figure 3. The teaching ways on freedom

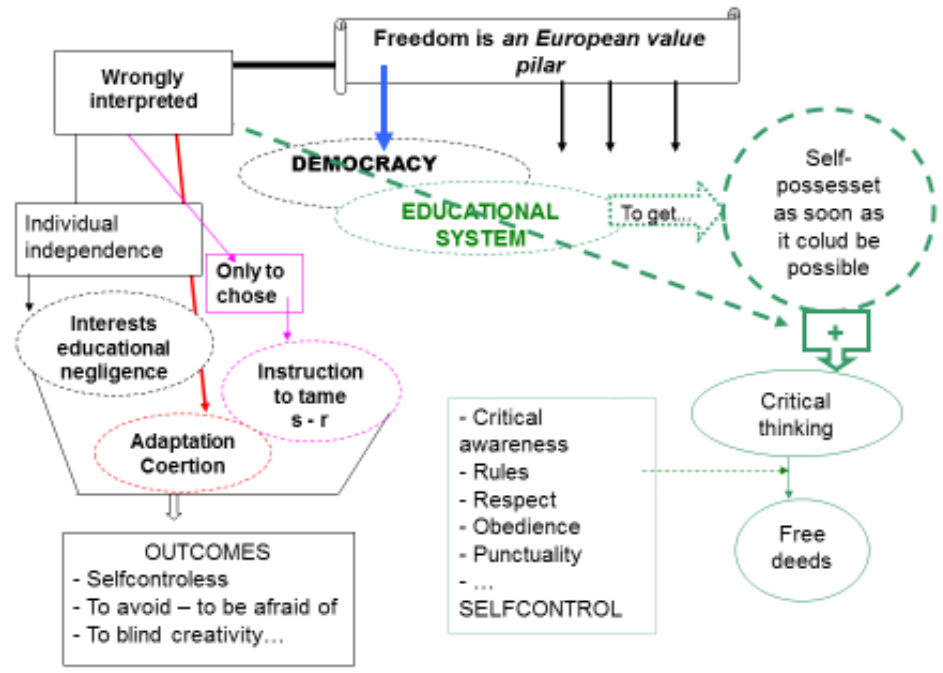

Schematically, Figure 3 shows antagonistic ways of understanding freedom. One that understands it as independence, which is only considered as the ability to choose, so the school should only be non-ethically, leaving schoolchildren to play their interests and relating people with adaptive or coercive styles that not promote a self-control (Huxley: A happy world, with Skinner's theory: Walden dos). The other way conceives democracy in freedom with the use of critical thinking, as means to achieve in each scholar, their own possession, which entails a series of virtues such as critical consciousness (discernment), norms, respect, ... (human virtues: Isaacs) for have an self-control, and, therefore, free actions in a freedom's environment. So, as it is before said (Peiró, 1982a), is necessary to inserter the Human Rights combined with skills coupled with knowledge and attitudes to reach a self-control (Sadio, 2011).

The Component Display Theory (Merrill, 1983) considers the transmission of the curriculum dividing the information in four dimensions: concepts, facts, procedures and principles and their presentation form in: rules, examples, memories and activities. Establishing a parallelism with education regarding freedom and its values, applying the general to this specific virtue, we have the following models, procedures and techniques (Peiró, 2013): A) The imitation (Sears, 1957; Whiting, 1960; Stotland, 1961, mentioned by Whittaker, 1979, 173). B) Changing of attitudes based on an informational approach, or by influence of third parties, stimulation, etc. (Morris, 1992). C) To promote empathic capacity in students (Elias et al, 2000; Bussenius, 2012). D) Develop philosophy lessons for school's children (Lipman, 1988). E) Values clarification (Howe y Howe, 1980). F) Promote moral reasoning by posing moral dilemmas (Kohlberg, 1989). G) Interacting with authority and control, focusing on rules and sanctions (García, 2008; Soria, 2008). H) Achieve morality through agreements carried out in assemblies and school debates (Wales, y Clarke, 2005). I) Instill values through a rote instruction (IbáñezMartín, 1983; Ramallo, 2012). J) Character education to achieve maximum self-control (GarcíaHoz, 1975; Ibáñez-Martín, 1983; Shaps et al, 2001). K) And for the achievement of an integrated education: to develop lessons of the curriculum with values, with a humanistic foundation (Ibáñez-Martín, 2010) from the perspective of an inter / transdisciplinary model (Peiró, 1982).

\section{HEURISTIC QUESTIONS}

In each group of values teaching dimensions, it has operated analogously to what is shown in Figure 4 (regarding the values teaching models). From a phenomenological and hermeneutical 
procedure was made (Smeyers, 2011), configuring a network to interpret axiological skills results' for the questionnaire's items (53a-53ah).

Figure 4. A nomological net for values teaching models

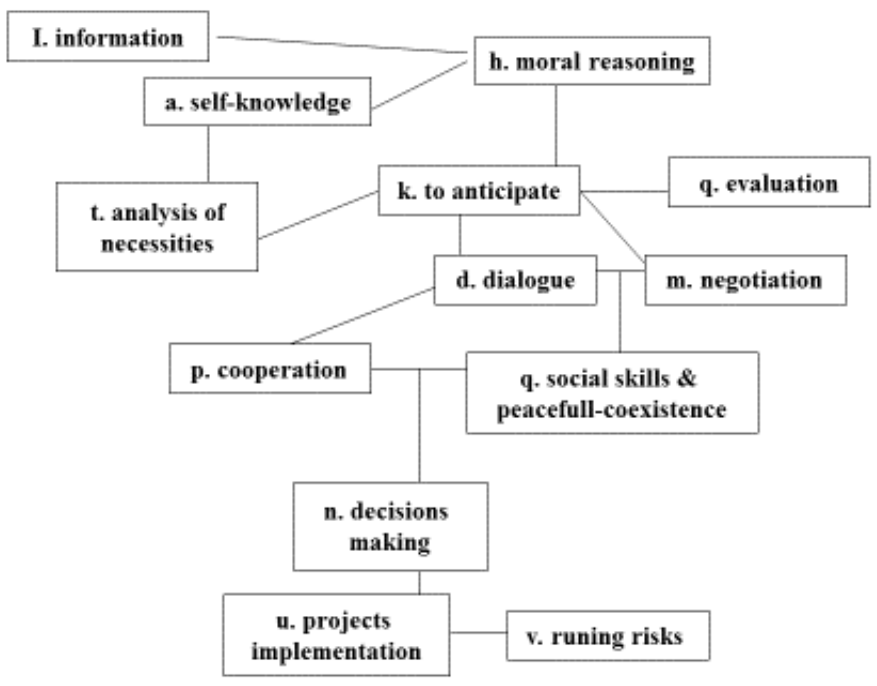

As has been said, the values and promotion of human virtues are key to preventing and modifying critical situations, as well as to channel conflicts. In this regard, we ask ourselves about the way to do it in the classrooms. Therefore, heuristic issues arise: a) How to teach humanitarian principles? b) How to promote Human Rights? c) What issues and values are promoted through the curriculum? d) Related to freedom, what issues \& values are promoted? e) Are there contradictions in the teachings? f) Is it possible to implement this model? g) Is it possible to implement such a model?...

\section{METHODOLOGY}

The population had surveyed wear teachers and students. The distribution by years/population is as follows: 2008: 1130, 2009: 995, 2010: 1468, 2011: 959.

Figure 5. Percentages of answers to the set of questions 47.

\begin{tabular}{|c|c|c|c|c|c|c|c|c|c|c|c|c|c|c|}
\hline YEARS & $\begin{array}{c}\text { ITEMS } \\
\text { SURVEYED } \\
\text { PEOPLE } \\
\text { NUMBER }\end{array}$ & $\begin{array}{l}47 \\
. a\end{array}$ & $\begin{array}{c}47 \\
b\end{array}$ & $\begin{array}{c}47 . \\
\text { c }\end{array}$ & $\begin{array}{c}47 . \\
d\end{array}$ & $\begin{array}{c}47 . \\
\text { e }\end{array}$ & $\begin{array}{c}47 . \\
\mathrm{f}\end{array}$ & $\begin{array}{c}47 . \\
\text { g }\end{array}$ & $\begin{array}{c}47 . \\
\text { h }\end{array}$ & $\begin{array}{c}47 . \\
\text { i }\end{array}$ & $\begin{array}{c}47 . \\
\text { j }\end{array}$ & $\begin{array}{c}47 . \\
\text { k }\end{array}$ & $\begin{array}{c}47 . \\
1\end{array}$ & $\begin{array}{c}47 . \\
\mathrm{m}\end{array}$ \\
\hline 2008 & 1130 & $\begin{array}{r}51,2 \\
\%\end{array}$ & $\begin{array}{r}75,4 \\
\%\end{array}$ & $\begin{array}{r}63,5 \\
\%\end{array}$ & $\begin{array}{r}79,9 \\
\%\end{array}$ & $\begin{array}{r}66,2 \\
\%\end{array}$ & $\begin{array}{r}64,8 \\
\%\end{array}$ & $\begin{array}{r}54,1 \\
\%\end{array}$ & $\begin{array}{r}70,0 \\
\%\end{array}$ & $\begin{array}{r}30,1 \\
\%\end{array}$ & $\begin{array}{r}69,4 \\
\%\end{array}$ & $\begin{array}{r}8,5 \\
\%\end{array}$ & $\begin{array}{r}81,1 \\
\%\end{array}$ & $\begin{array}{r}34,1 \\
\%\end{array}$ \\
\hline 2009 & 995 & $\begin{array}{r}57,7 \\
\%\end{array}$ & $\begin{array}{r}76,9 \\
\%\end{array}$ & $\begin{array}{r}51,0 \\
\%\end{array}$ & $\begin{array}{r}75,5 \\
\%\end{array}$ & $\begin{array}{r}70,9 \\
\%\end{array}$ & $\begin{array}{r}74,2 \\
\%\end{array}$ & $\begin{array}{r}62,2 \\
\%\end{array}$ & $\begin{array}{r}64,8 \\
\%\end{array}$ & $\begin{array}{r}44,1 \\
\%\end{array}$ & $\begin{array}{r}67,1 \\
\%\end{array}$ & $\begin{array}{r}19,2 \\
\%\end{array}$ & $\begin{array}{r}82,0 \\
\%\end{array}$ & $\begin{array}{r}17,5 \\
\%\end{array}$ \\
\hline 2010 & 1468 & $\begin{array}{r}53,6 \\
\%\end{array}$ & $\begin{array}{r}80,9 \\
\%\end{array}$ & $\begin{array}{r}44,3 \\
\%\end{array}$ & $\begin{array}{r}65,5 \\
\%\end{array}$ & $\begin{array}{r}69,3 \\
\%\end{array}$ & $\begin{array}{r}79,0 \\
\%\end{array}$ & $\begin{array}{r}64,5 \\
\%\end{array}$ & $\begin{array}{r}57,9 \\
\%\end{array}$ & $\begin{array}{r}46,5 \\
\%\end{array}$ & $\begin{array}{r}62,5 \\
\%\end{array}$ & $\begin{array}{r}27,9 \\
\%\end{array}$ & $\begin{array}{r}69,5 \\
\%\end{array}$ & $\begin{array}{r}9,3 \\
\%\end{array}$ \\
\hline 2011 & 959 & $\begin{array}{r}47,9 \\
\%\end{array}$ & $\begin{array}{r}75,9 \\
\%\end{array}$ & $\begin{array}{r}34,1 \\
\%\end{array}$ & $\begin{array}{r}57,9 \\
\%\end{array}$ & $\begin{array}{r}65,2 \\
\%\end{array}$ & $\begin{array}{r}69,8 \\
\%\end{array}$ & $\begin{array}{r}58,1 \\
\%\end{array}$ & $\begin{array}{r}46,8 \\
\%\end{array}$ & $\begin{array}{r}45,5 \\
\%\end{array}$ & $\begin{array}{r}58,7 \\
\%\end{array}$ & $\begin{array}{r}31,9 \\
\%\end{array}$ & $\begin{array}{r}61,9 \\
\%\end{array}$ & $\begin{array}{l}7,8 \\
\%\end{array}$ \\
\hline
\end{tabular}

However, there are no unanimous answers. To understand it, let's see an example by Figure 5, showing the percentages of each annual group and answers for each item $\&$ by year. 
A model that relates theory to reality was made (Peiró, 1998). This instrument is the questionnaire to survey. Tis consists on a part of the 83 items' located in http://violencia.dste.ua.es in tab convivencia, insiting in this by the key: p_estudio, readers could be analyzed all its parts. Each question is formulated in a Likert-type scale, for later calculations, facilitating a rate of the teachers, according to the intensity with which them practice, following the same scale and within the parentheses, namely: always (5) almost always (4) sometimes (3) rare (2) never (1).

Considering other convenient questionnaire's sections for this study, we have the following questions:

50. When working on certain axiological issues, what is the main objective you intend to achieve? () Inculcate the values that I personally understand, so that your student is good. () Motivate students to think and decide for themselves. () Influence so that the behavior of the student changes. () Improve compliance with standards within the classroom. () Get more discipline and order to be able to work. () Others (specify).

51. Of the topics listed below, which ones teach or have you taught? Please rate them according to the intensity with which teachers and teachers practice them, following the same scale and within the parentheses, namely: always (5) almost always (4) sometimes (3) rare (2) never 0 Self-knowledge. (O Relationship between partners. () Relations in the family. 0 Discrimination based on gender. () Coexistence in school. () Skills for dialogue. () Scientific and technological advances. () Ecological problem. () The diversity of the students. () Human rights. O Civics. () The values established by the Education Law. O Constitutional values. () Others (specify).They have been selected the teaching-themes, procedures, and so on concerning freedom's teaching. Then, a questionnaire was drawn up, such as the Figure 4, which represents the structure of the item 51. Moreover, concerning the teaching-themes more concerned with the freedom, these are the following: Self-knowledge, the Human Rights, Civics, Values Educational Law's, and Constitutional values.

The follow statistics was calculated "t" (of Student), that ensures there is no statistical error to work at the confidence's level of 95\%.

Other statistics was calculated, this are: $\mu$ averages, $\sigma$ standard deviations $(2008: 0,119,2009$ : 0,302, 2010: $0,123,2011: 0,082$ ). It is noted that all are $<1$, so the $\mu$ statistics are closed.

Bearing in mind that Person's correlation does not give us any information, because items are elaborated by scale and the others is binary, then dispersion diagram draw us unrelated data, since there are only 10 possible points. Accordingly, the calculation of Chi-square was made.

$\chi^{2}$ Chi-square in order to draw inferences. The more likely the items compared are to be independent; and vice versa, the higher the value, there will be more dependence between the data pairs (Monje y Pérez, s/f). For our case, calculating with a degree of confidence of $5 \%$, those who give $\chi^{2}>9,488$ will be dependent; if $\chi^{2}<0.711$ we have that they are independent.

The Figure 6, on questionnaire items \& findings, at the third of the columns, the rest of the most significant questions for this study, in relation to the previous theoretical reflections and the results are offered.

As an empirical method in not enough to make decisions, but helps for it, rely not only research on the interpretation of empirical data, the hermeneutics and phenomenology (Smeyers, 2011) to build relationships between issues, values and reality are both used. 


\section{FOUNDS}

Taking the data corresponding to the enunciation of the manuscript, we can make a double entry box (Fig. 6).

Figure 6. Questionnaire's items \& findings

\begin{tabular}{|c|c|c|c|}
\hline $\begin{array}{c}\text { From the theoretical } \\
\text { framework }\end{array}$ & Emerging issues & \begin{tabular}{|c|}
$\begin{array}{c}\text { Questionaire's } \\
\text { items }\end{array}$ \\
\end{tabular} & Funds concerning of questions \\
\hline $\begin{array}{l}\text { 1. Conflicts, } \\
\text { solutions. Peace. }\end{array}$ & $\begin{array}{l}\text { a) How to teach } \\
\text { humanitarian } \\
\text { principles? }\end{array}$ & 51 & $51 \mathrm{dd}$ ) The respect: $55-88 \%$ \\
\hline $\begin{array}{l}\text { 2. Opposition to the } \\
\text { authoritarian model. }\end{array}$ & $\begin{array}{l}\text { b) How to promote } \\
\text { Human Rights. }\end{array}$ & 51 & 51 c) The dialogue: $70-78 \%$ \\
\hline $\begin{array}{l}\text { 3. Promoting choice } \\
\text { and elicitation of self- } \\
\text { peoposals. Rights and } \\
\text { duties. }\end{array}$ & $\begin{array}{l}\text { b) How to promote Human } \\
\text { Rights. }\end{array}$ & $\begin{array}{l}4 \\
9 \\
5 \\
1\end{array}$ & $\begin{array}{l}\text { 49b) "Relationship with partners" } \\
(80-90 \%) \\
51 \text { a) Self-knowledge: } 70 \% \text { and } 51 \mathrm{n} \text { ) to } \\
\text { make decision: } 70 \% \text { united } 51 \mathrm{p}) \text { to } \\
\text { cooperate: } 45-70 \%) ;\end{array}$ \\
\hline $\begin{array}{l}\text { 4. To develop the } \\
\text { personality for making a } \\
\text { critical way }\end{array}$ & $\begin{array}{l}\text { d) Related to freedom, } \\
\text { what issues \& values are } \\
\text { promoted? }\end{array}$ & 49 & 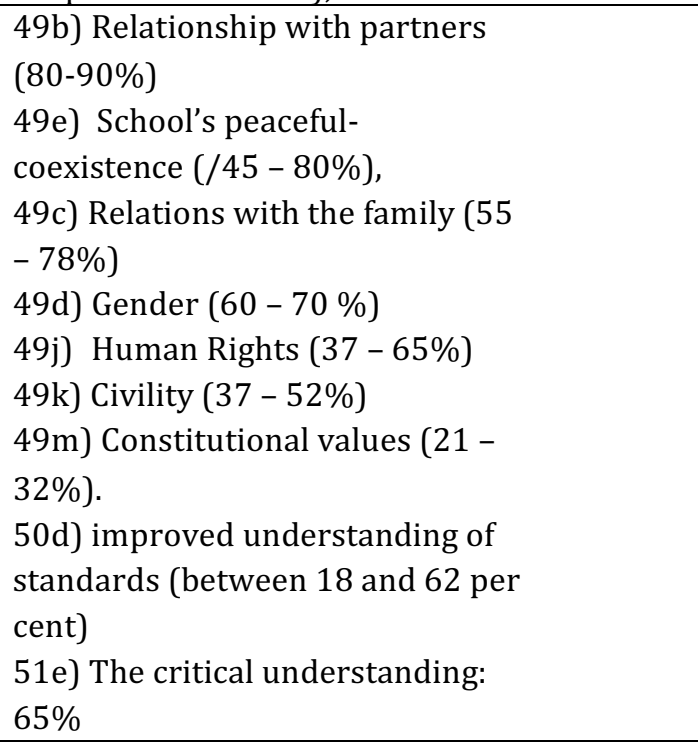 \\
\hline $\begin{array}{l}\text { 5. Promote human } \\
\text { virtues, rather than } \\
\text { normalizing. }\end{array}$ & $\begin{array}{l}\text { c) What issues and } \\
\text { values are promoted } \\
\text { through the } \\
\text { curriculum? }\end{array}$ & 50 & $\begin{array}{l}\text { 50e) maintain order and discipline (around } \\
50 \% \text { ). }\end{array}$ \\
\hline $\begin{array}{l}\text { 6. Inter / trans- } \\
\text { disciplinarian } \\
\text { curriculum. }\end{array}$ & $\begin{array}{l}\text { e) Are there contradictions } \\
\text { in the teachings? }\end{array}$ & $\begin{array}{r}5 \\
\\
5 \\
1 \\
60,61 \\
62.65\end{array}$ & $\begin{array}{l}50 \mathrm{~b} \text { ): motivate them to self- } \\
\text { decision: between } 65 \% \text { to } 85 \% \\
\chi^{2} \text { among items } 51 \mathrm{a}, 51 \mathrm{e}, 51 \mathrm{j} \text { and } 51 \mathrm{k} \text {, respect } \\
\text { others } 60,61,62,65, \\
66,67 \text { and } 68 .\end{array}$ \\
\hline $\begin{array}{l}\text { 7. Don't force, even for } \\
\text { a proposal of minimum } \\
\text { values. }\end{array}$ & $\begin{array}{l}\text { b) How to promote Human } \\
\text { Rights. }\end{array}$ & 51 & $\begin{array}{l}\text { 51a) The self-knowledge: } 70 \% \text { and } \\
\text { 51n) to make decision: } 70 \% \text { united } 51 \mathrm{p} \text { ) } \\
\text { to cooperate ( } 45 \text { - } \\
70 \%)\end{array}$ \\
\hline $\begin{array}{l}\text { 8. Students keep } \\
\text { their self-control. }\end{array}$ & $\begin{array}{l}\text { f) Is it possible to } \\
\text { implement this } \\
\text { model? }\end{array}$ & 51 & 51b) Autonomy-self-regulation (45 - 65\%). \\
\hline
\end{tabular}

The first column synthesizes the theoretical framework in 8 sentences. The second vertical series refers to the questions that are interpreted from the 8 mentioned theses. Next, the numbers of the items corresponding to the questionnaire are written. The last column shows the percentages that the respondents give to each issue question. 
To know the objectives (Fig. 7) that the schools intend to achieve in relation to such values (items 50-50f), the most important items are selected: (50b): motivate them to make selfdecisions (between 65\% and 85\%); (50d) improved understanding of standards (between 18 and 62 per cent) \& (50e) maintain order and discipline (around 50\%).

Figure 7. The objectives on values teaching.

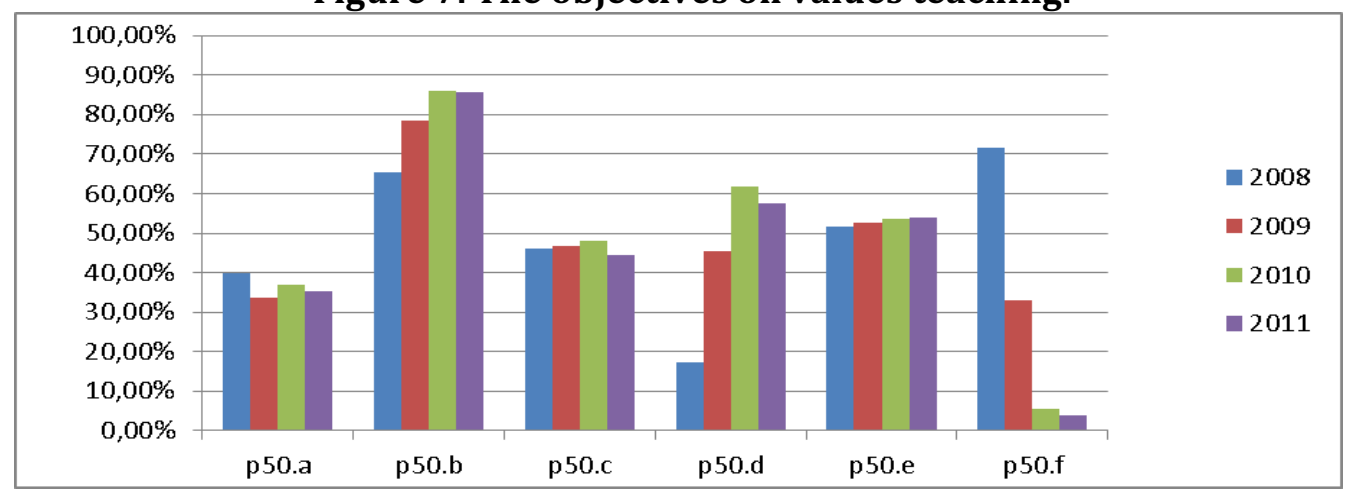

As well, the themes in teaching (Fig. 8: ítems: 51a-n): 51b) Relationship with partners (8090\%), 51e) School's peaceful-coexistence (/45 - 80\%), 51c) Relations with the family (55 $78 \%), 51 d)$ Gender discrimination (60 - $70 \%$, 51j) Human Rights (37 - 65\%), 51k) Civility (37-52\%), \& 51m), and Constitutional values $(21-32 \%)$.

Figure 8. The axiological themes teaching.

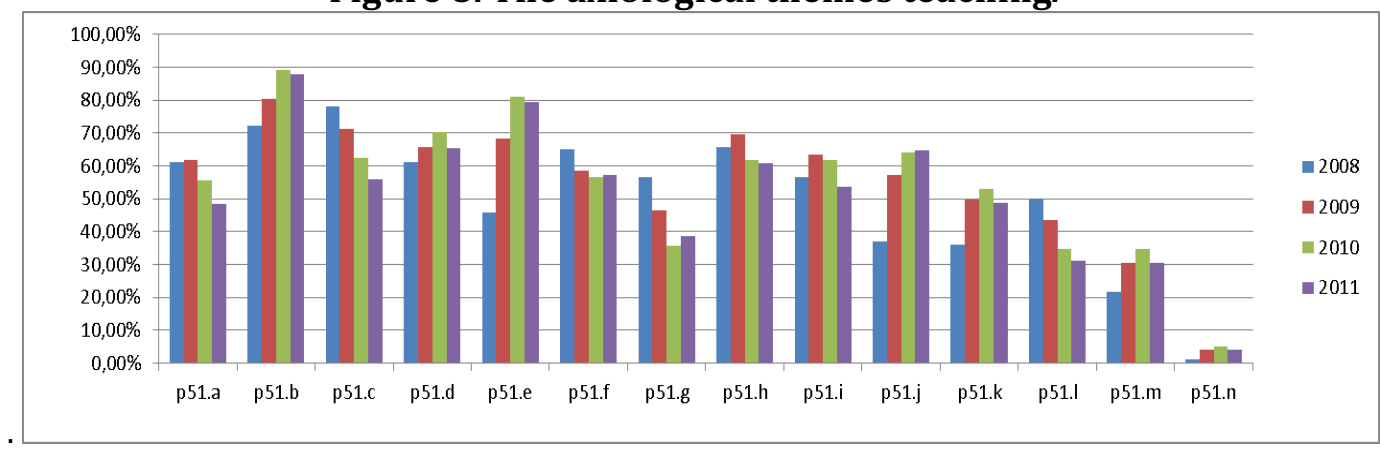

As it was said in the state of the 53 question (Figure 9), it is necessary to contemplate the approach of the teachings on skills, abilities... teaching. The empirical calculation of means offers the following theoretical aspects taking prevalence over community interactions. The results are: $53 \mathrm{c})$. The prevalent is the dialogue (70-78\%), 53ad) the respect (55-88\%), 53a) the self-knowledge (70\%) and $51 \mathrm{n}$ ) to make decisions (70\%) united, 51p), to cooperate (45$70 \%) ; 53 e)$, a critical understanding (65\%), \& 53b), lighter weight is autonomy-self-regulation $(45-65 \%)$.

Figure 9. The skills, abilities... teaching.

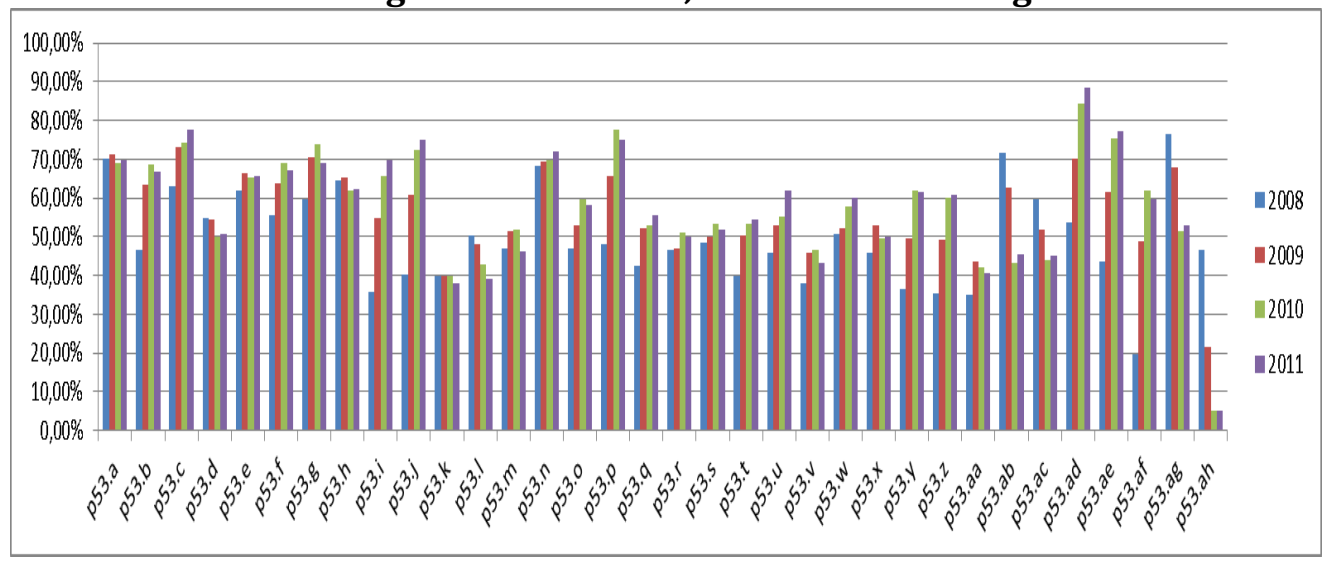


Figure 10. Teaching procedures and techniques $\%$

\begin{tabular}{|l|l|l|l|l|l|l|l|l|l|l|l|l|l|}
\hline & 47a & $\mathbf{4 7 b}$ & $\mathbf{4 7 c}$ & $\mathbf{4 7 d}$ & $\mathbf{4 7 e}$ & $\mathbf{4 7 f}$ & $\mathbf{4 7 g}$ & $\mathbf{4 7 h}$ & $\mathbf{4 7 i}$ & $\mathbf{4 7 j}$ & $\mathbf{4 7 k}$ & $\mathbf{4 7 1}$ & $\mathbf{4 7 m}$ \\
\hline $\mathbf{2 0 0 8}$ & 51,47 & 73,73 & 63,73 & 80,27 & 66,49 & 65,07 & 54,31 & 70,31 & 30,22 & 69,69 & 8,53 & 81,42 & 34,22 \\
\hline $\mathbf{2 0 0 9}$ & 57,80 & 77,04 & 51,06 & 75,63 & 71,00 & 74,32 & 62,34 & 64,95 & 44,21 & 67,27 & 19,23 & 82,18 & 17,52 \\
\hline $\mathbf{2 0 1 0}$ & 54,84 & 82,79 & 45,30 & 67,04 & 70,94 & 80,77 & 65,99 & 59,23 & 47,53 & 63,97 & 28,57 & 71,08 & 9,48 \\
\hline $\mathbf{2 0 1 1}$ & 52,85 & 84,67 & 37,36 & 68,19 & 73,41 & 77,32 & 66,88 & 53,02 & 51,55 & 65,58 & 36,54 & 70,15 & 8,81 \\
\hline
\end{tabular}

As shows Fig. 10, the most used procedures are: debates, clarification of values, change of attitudes, cultural activities, moral reasoning. The least used are: moral dilemmas and philosophy for school children. Assemblies and the performance of roles would be in an intermediate acceptance, although the lessons with values are a little higher than the last ones. If the results are criticized pedagogically, a certain contradiction is found, even among the most practiced. We also have the paradox of highlighting moral reasoning and reducing the use of dilemmas, being two names of the same reality.

Figure 11. Curricular structure of the teaching of such values.

\begin{tabular}{|c|c|c|c|c|}
\hline & 52a & 52b & 52c & 52d \\
\hline $\mathbf{2 0 0 8}$ & 58,64 & 13,36 & 58,25 & 52,16 \\
\hline $\mathbf{2 0 0 9}$ & 56,22 & 16,74 & 52,79 & 29,83 \\
\hline $\mathbf{2 0 1 0}$ & 58,79 & 17,43 & 45,86 & 12,36 \\
\hline $\mathbf{2 0 1 1}$ & 48,75 & 24,38 & 50,71 & 9,79 \\
\hline
\end{tabular}

Interpreting the table, a few brief considerations can be said. The teaching of the values concerning the freedom in peacefull-coexistence are not systematized by areas or departments, few are doing so (between 13.36 and 24.38). The majority, without reaching $60 \%$, teach in the form of transversal knowledge, and a percentage located around 50\% promotes them in the tutorials ways. For the sum of percentages, there is a combination of both procedures.

The Chi-squared test $(\chi 2)$ among the most outstanding items was calculated (Figure 12).

Figure 12. Relationships: values performance and school civility.

\begin{tabular}{|c|c|c|c|c|c|c|c|}
\hline $\begin{array}{l}\text { Behaviours' } \\
\text { students. } \\
\text { Themes of } \\
\text { Teaching. }\end{array}$ & $\begin{array}{c}60 \\
\text { Imple- } \\
\text { ment } \\
\text { ruls }\end{array}$ & $\begin{array}{c}61 \\
\text { Not be } \\
\text { bothe- } \\
\text { red }\end{array}$ & $\begin{array}{c}62 \\
\text { Not } \\
\text { disor- } \\
\text { der } \\
\text { with } \\
\text { teache } \\
r\end{array}$ & $\begin{array}{c}65 \\
\text { There } \\
\text { are } \\
\text { quarrel }\end{array}$ & $\begin{array}{c}66 \\
\text { Work } \\
\text { witout } \\
\text { teacher }\end{array}$ & $\begin{array}{c}67 \\
\text { Don't } \\
\text { respect } \\
\text { for } \\
\text { teacher }\end{array}$ & $\begin{array}{c}68 \\
\text { Rampage } \\
\text { in } \\
\text { classroom } \\
\text { without } \\
\text { teachers }\end{array}$ \\
\hline $\begin{array}{l}\text { 51.a Self- } \\
\text { knowledge }\end{array}$ & 11,78 & 3,94 & 9,13 & 2,81 & 10,14 & 9,72 & 18,13 \\
\hline $\begin{array}{l}\text { 51.e School's } \\
\text { peacefullco } \\
\text { existence }\end{array}$ & 31,20 & 44,80 & 7,51 & 35,27 & 9,13 & 22,23 & 22,24 \\
\hline $\begin{array}{l}\text { 51.j } \\
\text { HumanRights }\end{array}$ & 6,37 & 3,11 & 8,21 & 18,13 & 11,15 & 9,91 & 11,91 \\
\hline $\begin{array}{ll}51 . K^{2} & \\
& \text { Civics }\end{array}$ & 13,84 & 8,86 & 11,91 & 35,12 & 11,98 & 15,08 & 12,34 \\
\hline
\end{tabular}

There are the dependent variables because clear independent variables does not exist. There are not despicable relationships between items and behaviors. The couples with $\chi^{2}>9,488$ are more related, they are interdependent: A) Self-knowledge shows dependence with: complying with the rules, not disturbing as much as the teacher does not present, they do not respect the teacher, and there are disturbances when the teacher is not there. B) When peacefullcoexistence (civility in freedom) is taught, the same thing usually happens as what is described 
for A. C) The teaching of human rights shows dependencies with: fights, work without a teacher, disrespectful with the teacher and disturbances without the presence of the teacher. D) Teaching citizenship shows dependence with: complying with the rules, but there is disorder and fights, they work even when the teacher is not there and there are riots. This leads us to lower that activities on personalization are more educational than learning subjects.

\section{DISCUSSION AND CONCLUSIONS}

If liberal democracy is the institutionalization of Human Rights, as a most practical solution to the freedom of each human being compatible with the freedom of all, it would be convenient for teachers to understand the need to integrate human and social values. This is so that the results of teaching and learning do not remain in mere rational exercise.

The issues and values related with freedom are promoted through the curriculum are consistent with the statements mentioned in the theoretical framework. Generally, schools not educated with no limits or allowing the spontaneity of the desires, or the full power of a collective.

The teaching of aspects of the semantic field of peace are understood in the curriculum as notions about human rights, self-knowledge, teaching regulations, constitutional values, coexistence, self-knowledge and critical thinking. It does not follow that it develops more personalizing than intellectual. Nevertheless the model is largely procedural, although there are some authors that supplement it, taking into account the full development of subjectivity with human virtues and self-management. Therefore, the need to be supplemented is appreciated.

A way to complete the procedural approach would be the appeal to the solution of conflicts (items 60 -68), to build each and / or group the necessary values to solve it and the actions so that they become virtues within the community-classroom (freedom in and for).

About how to teach humanitarian principles. When it is intended only motives or understanding of the rules (item 50), it is taking whole freedom in an external approach to the depth of the self. Therefore, education for full freedom is not complete, because it is not clear that there are content with human values, which would give the "do the good you want."

On to promote Human Rights. There is a certain ambiguity between the transversal (item 48) and notional approach of the values and themes, and on the other hand (items 49) indicate the interaction between equals, as well as encouraging (item 51) critical thinking, self-knowledge, deciding or cooperating. However, they could be understood as consecutive parts of the same process.

Related to freedom, on issues \& values promoted, the prevalent ones are: to promote good relations with classmates; the understanding of school's peaceful-coexistence; foster good family relationships; notion of gender; understand human rights and citizenship; the values of the constitution; understand school regulations; and develop critical thinking.

However, as some references on the state of the question appealed to the core of freedom, which is specified with other values, such aspects have not been added to the open questions. So the curriculum development is insufficient. Perhaps, the tutorial approach (punctuated in all near 50\%) should be researched on knowing if such virtues are contemplated in such educational dimension.

It shall be possible to implement an integrated model. Since the item $51 \mathrm{~b}$ would lead us to consider an aspect that would conjoin the freedom of and for: autonomy and self-regulation. 
This aspect is scored between 45 to 65 percent of the answers. However, with the survey procedure this aspect is unrecognizable, it should be placed in the classrooms to analyze (micro-teaching) and also make a hermeneutics of the exercises of the students.

It has been expressed that, the teaching of values related to freedom, have focused on the development of cross-cutting issues, but also on developing tutorial interactions. As it is said about the couples, the chi-square leads us to infer that are more educational activities on customizing learning of subjects, without expressing that the latter does not contribute to the formation. So, it seems tutorials offers better results than lessons. On this, we should find out how are developing the firts.

Considering the correlations, there is a certain doubts regarding the implementation of the procedural model. That statement is based on, if the constitutional values are indicators of the human rights' realization, as well as the civility, which is incarnate at school as peacefulcoexistence, it could be noted that there are an inconsistency between this declarations and the real misbehaviours. This could be caused by the mere memoristic approach, or understanding it with some affective education in values relative to the freedom.

In short: The model of education in / for freedom indeed is collected in the schools, as teachers refer in its answers.

\section{PRESCRIPTIONS}

The university curriculum for initial teacher training, should include educational courses for to provide criteria that teachers to be able to:

A) Know the effects of values, attitudes and virtues in the structuring of each student's self, and the importance of educating in / for true and full freedom.

B) Relate pupils' educability, anthropology and axiology concerning pedagogical and didactic derivations. This means that they know the different models of educating in values and their effectiveness in terms of educational personalization.

C) Provide criteria for teachers to fulfill themselves professionally, including ethical review.

The questionnaire should be completed in order to compare with interviews, exercise interpretations, meetings, discussion groups, etc.

Linked to the aforementioned transversality, it would be convenient for teachers to know the epistemology of interdisciplinarity, especially transdisciplinarity, by referring it to the values surrounding freedom in the exercise of teaching: lessons, tutoring, peer interactions.

\section{References}

Agulló, A. (2013). Sútil tiranía de la normalidad. http://www.fluvium.org/textos/etica/eti1121.htm

Arendt, H. (2002). Condition de l’homme moderne. París, Ágora.

Barrio, J.M. (2003) Tolerancia y cultura del diálogo. Revista Española de Pedagogía, LXVIII, num.247.

Beesley, ZM. (2016). "Education is a necessity of life", John Dewe. Articles on Economic and Commerce Education. https://zoemariebeesley.com/2016/06/26/education-a-necessity-of-life-john-dewey/_Retrieved 27/07/2017.

Bussenius, H. C. (2010). Programa para desarrollar la empatía.

http://praxischile.blogspot.com.es/2010/08/programa-para-desarrollar-la-empatia.html Retrieved 12/08/2012

Cabello, M. J. (2003). Education today: two complementary stories and different narratives. European Educational Research Journal, vol. 2, num. 2, 2003.

Cato Institute (2017). Educational Freedom. https://www.cato.org/education-wiki/educational-freedom Retrieved 04/11/2017.

CSH - Committee on School Health (2003). Out-of-School Suspension and Expulsion. The American Academy of Pediatrics http://pediatrics.aappublications.org/content/112/5/1206 Retrieved 12/12/2011 
Connolly, D. and Ospina, J. (2016). Education as Freedom. The Hague Institute for Global Justice. http://www.thehagueinstituteforglobaljustice.org/latest-insights/latest-insights/commentary/education-asfreedom/ Retrieved 04/11/2017.

Dewey, J. (1916). Democracy and Education: An Introduction to the Philosophy of Education. Macmillan.

Dovemark, M. (2004). Pupil Responsibility in the Context of School Changes in Sweden: market constraints on state policies for a creative education. European Educational Research Journal, Vol. 3 Num. 3, 2004.

Elias, M.J.; Tobías, S.E. y Friedlander, B.S. (2000). Educar con inteligencia emocional. Barcelona, Plaza y Janes.

Elzo, J. (2006). Jóvenes y valores, la clave para la sociedad del futuro. Fundación La Caixa. Barcelona,

Fabro, C. (1983). Reflessioni sulla libertà. Maggioli, Rimini.

Fernández-Llébrez, F. (2009). Jóvenes y democracia. Jovencuentro, diciembre de 2008 (Página Abierta, 199-200, enero-febrero de 2009). http://www.pensamientocritico.org/ferfer0309.html Retrieved 27/10/2017

Foa, R. \& Munk, Y. (2015). Are Americans losing faith in democracy? Vox, Dec 18, 2015 https://www.vox.com/polyarchy/2015/12/18/9360663/is-democracy-in-trouble

Foray, P. (2011). Philosophy and the Rationalisation of Educative Action: the example of personal autonomy. European Educational Research Journal, Vol.10.Num.3.

García, A. (2008). La disciplina escolar. Murcia: Universidad de Murcia.

García Hoz, V. (1975) Educación personalizada. Valladolid, Miñón

Gonçalves, S. (2004). Key areas in value education. Value Education European Module. ESEC, Coimbra. 141ss.

Hill, B. V. (2004). Values education in schools. Issues and Challenges. Forum in Melburne. http://www.curriculum.edu.au/verve/_resources/ve_acsa_paper.pdf Retrieved 22/12/2008

Hjort, K. (2006) De-democratisation in Denmark? European Educational Research Journal, Vol. 5 Num. 3.

Howe, L. y Howe, M. (1980). Cómo personalizar la educación. Perspectivas de la clarificación de valores. Madrid: Ediciones Santillana.

Ibáñez-Martín, J. A. (1983) Adoctrinamiento. Diccionario de Ciencias de la Educación. Madrid, Santillana.

Ibáñez-Martín, J. A. (2010). ¿Llenar el vaso o encender el fuego? Viejos y nuevos riesgos en la acción educativa. Lección Inaugural del Curso Académico 2010-2011. Facultad de Educación. Universidad Complutense de Madrid.

Jackson, J. (2014). The democratic individual: Dewey's back to Plato movement. The Pluralist, 9(1), 14-38. Retrieved 09/05/16 http://www.ebscohost.com/

Kohlberg, L. (1989). Estadios morales y moralización. El enfoque congnitivo-evolutivo, en Turiel, E.; Enesco, I. y Linaza, J. El mundo social en la mente infantil. Madrid: Alianza.

Levinson, (1996). The End of Education. Redefining the Value of School. Harvard Educational Review, Winter. Retrieved 09/05/16 http://hepg.org/her-home/issues/harvard-educational-review-volume-66-issue4/herarticle/redefining-the-value-of-school_287 Consultada el 02/10/2017

Lipman, M. (1988). Philosophy goes to School. Philadelphia, Temple University Press.

Merrill, M.D. (1983). Component Display Theory. In C. Reigeluth (ed.). Instructional Design Theories and Models. Hillsdale, NJ: Erlbaum Associates. 1983.

Meyer, M.A. (2007). Didactics, Sense Making, and Educational Experience, European Educational Research Journal, vol.6, num.2.

Millán-Puelles, A. (1988). La formación de la persona. AAVV: El pensamiento filosófico-pedagógico de Jacques Maritain. Madrid, San Pablo CEU.

Millán-Puelles, A. (2009). El valor de la libertad, Madrid, Rialp.

Monje, J. F. y Pérez, A. A. (s/f). Estadística no paramétrica: Prueba chi-cuadrado $\chi 2$. Proyecto e-Math1 https://www.uoc.edu/in3/emath/docs/Chi_cuadrado.pdf Retrieved 10/10/2011.

Monrós-Sánchez, S. (2013). Cómo educar la autoestima en educación infantil. Repositorio digital. Universidad de la Rioja. http://reunir.unir.net/handle/123456789/1851 Consultado 10/12/2011.

Morris, Ch. (1992). La Psicología: Un nuevo enfoque. 7a ed. México: Prentice-Hall Hispanoamericana, S.A.

Moshman, D. (2003). Intellectual Freedom for Intellectual Development. Liberal Education, Summer. http://www.aacu.org/liberaleducation/le-su03/le-su3feature2.cfm Retrieved 09/10/2011 
Musso, J. (2003). Qu'est-ce que l'inhumain? Approches de la Philosophie, Portail Philosophic. http://www.philoplus.com/philos/dissert2.php Retrieved 12/07/2017

Nyroos et alii, (2004). A Matter of Timing: time use, freedom and influence in school from a pupil perspectiva. European Educational Research Journal, Vol.3, Num.4.

Philippou, S. (2005). The 'Problem' of the European Dimension in Education: a principled reconstruction of the Greek Cypriot currículo. European Educational Research Journal, Vol.4, Num.4.

Powell, J. (2010). Public Schools and Social Conflicts. https://www.fff.org/explore-freedom/article/publicschools-social-conflicts/ Retrieved 07/03/2016

Ramallo, P. (2012). ¿De qué sirve la educación? (II) Educación versus Instruir. Desde la sociedad civil. http://idsc.me/2012/06/12/de-que-sirve-la-educacion-ii-educacion-versus-instruir/ Retrieved 12/06/2012

Reyero, D. (2003). La libertad y su incidencia en la educación. Revista Española de Pedagogía, no 226.

Rogers, C. R. (1996). Libertad y creatividad en la educación. Barcelona, Paidós Ibérica.

Rothbard, N. M. (1999). Education Free \& Compulsory. Alabama, The Ludwig von Mises Institute.

Rubiales, F. (2017). Demasiados jóvenes españoles nos conducen hacia la dictadura. http://www.votoenblanco.com/Demasiados-jovenes-espanoles-nos-conducen-hacia-la-dictadura_a6867.html Retrieved 28/11/2017.

Sadio, F. (2011). V. II. Sobre la Educación para los Derechos del Hombre: fundamentos, práctica y actividades educativas. Exedra, número especial.

Schaps, E., Schaeffer, E. F., \& McDonnell, S. N. (2001). What's right and wrong in character education? Education Week, 2/(2), September 12, pp.40-44. 23.

Sedley, L.J.S. (1999). Freedom, Law and Justice. Sydney (Australia), Sweet \& Maxwell.

Sellés, J. F. (2014). Estudio de las tesis centrales de Millán-Puelles sobre la libertad. Naturaleza y Libertad. Revista de estudios interdisciplinares, núm. 4. Retrieved 07/11/2015 en

http://www.uma.es/naturalezaylibertad/resources/Vol_4_2014/NL-04-2014-6-Selles.pdf

Smeyers, P. (2011). Philosophy of ... Philosophy and ...: taking the conditions we find ourselves in seriously, European Educational Research Journal, vol.10, num.3.

Soëtard, M. (2011). Philosophy of Education: a thorn in the (clay) foot of the educational system, European Educational Research Journal, vol.10, num.3.

Soria, R. (2008). El derecho educativo en las normas de convivencia escolar. Retrieved 13/02/2012 http://portal.educar.org/docsove/elderechoeducativoenlasnormasdeconvivenciaescolar

Spaemann, R. (2001). La dictadura de los valores. Project Syndicate and Institute for Human Sciences, August 2001 http://www.project-syndicate.org/commentary/spaemann1/Spanish Retrieved 20/12/2011.

Torto, A. (2013). Come reconoscere i sintomi dissociativi. Posted by Igor Vitale in Psicologia Clinica on 2017/07/ 17 http://www.igorvitale.org/2013/07/17/come-riconoscere-i-sintomi-dissociativi/ Retrieved 23/12/2015.

Trapani, G. J. (2004). Truth Matters: Essays in Honor of Jacques Maritian. Washington, The Catholic University of America Press: American Maritian Association.

Touriñán, J. M. (2006). Educación en valores y experiencia axiológica: el sentido patrimonial de la educación. Revista Española de Pedagogía, num. 234, mayo-agosto 2006.

Unicef (2011). Clima, conflictos y violencia en la escuela. Fondo de las Naciones Unidas para la Infancia (UNICEF) Facultad Latinoamericana de Ciencias Sociales (FLACSO). Argentina.

Vik, I. and Endresen, C. (2017). Norway, religion and the United Nations, in: Stensvold, A. Religion, State and the United Nations. London, New York, Routledge.

Wales, J. y Clarke, P. (2005). Learning Citizenship: practical teaching strategies for secondary schools. London: Routledge Falmer.

Wahlström, N. (2009) Understanding the Universal Right to Education as Jurisgenerative Politics and Democratic Iterations. European Educational Research Journal, Vol.8, num. 4, 2009.

Whittaker, J. O. (1979). La psicología social en el mundo de hoy. México: Trillas 